\title{
Marketing issues of the eighties
}

\author{
Hazel T. Suchard \\ College of Business Administration, University of Hawaii at Manoa
}

\begin{abstract}
Important aspects of marketing in the Eighties are identified and analysed. Economic factors, consumerism and consumer movements as well as legislation, demographic changes, technological developments, international events, and interna. tional competition and the influence of alf these factors upon marketing strategy is discussed. Finally, changes in important components of a future marketing strategy are presented.

S. Afr. J. Bus. Mgmt. 1983, 14: $75-79$

Kernaspekte van bemarking in die tagtigerjare word geïden. tifiseer en geanaliseer. Ekonomiese faktore, die verbruiker en aanverwante bewegings sowel as wetgewings, demografiese veranderinge, tegnologiese ontwikkelinge, internasionale gebeure en internasionale kompetisie en die invloed van al hierdie faktore op die bemarkingstrategie word bespreek. Laastens word veranderinge in belangrike komponente van 'n toekomsgerigte bemarkingstrategie dan aangetoon. Hierdie komponente sluit produkstrategie, prysstrategie, promosiestrategie en verspreidingstrategie in.

S.Afr. Tydskr. Bedryfsl. 1983, 14: 75-79
\end{abstract}

Marketing issues of the eighties are many and varied. In what follows only some of the important issues will be discussed, specifically economic factors, consumerism, demographic changes, technological developments, international events and competitors and changes in the components of future marketing strategy.

\section{The economy}

Marketers do not exist in isolation but are very much affected by economic forces. One of the factors affecting consumers and home marketers world wide is the effects of inflation. While in some countries, for example, the U.S.A. inflation is more under control, it is still persisting, albeit at a decreasing rate. In other countries, for example, South Africa, inflation is continuing at an increasing rate.

Inflation has an impact on consumer lifestyles. Research studies have shown that consumption patterns are changing. ${ }^{1}$ There is an attempt to eliminate waste and the postponement of the purchase of consumer durables. As far as food is concerned a lesser variety is bought. There is a new functionalism in that the functional aspects of a product are now stressed, for example, the worth of a motor car may be assessed in terms of $\mathrm{kms}$ per litre. Consumers are concerned with durability - 'how long will it last?' is a common question. Consumers now make their own products ranging from picture frames and furniture to bread and cakes. As far as entertainment is concerned there is an increase in home entertaining and less expensive amusements are substituted for more expensive ones. Generally there is a trend towards a simpler way of life, far less is spent and shoppers have a greater awareness of prices and changes in prices and engage in comparative shopping. Comparative shopping may lead to the expansion of brand-loyalty and brand switching, the stocking up of what are considered 'bargain items'. Table I presents an example of a survey that illustrates the fact that consumers spend less and feel deprived - it covers the period between 1976 and 1980, a period of increasing inflation. ${ }^{2}$

It can be seen from these surveys that of the 200 adults surveyed, a rising proportion spent less on food, utilities and gasoline and when prices increased by $18 \%$, annual rate, in the first quarter of 1980 , nearly one-quarter of 1400 adults surveyed said they could afford 'hardly any' of the things they wanted.

As a result of the decrease in real income, other members 
Table 1 The economy's impact on consumers. Inflation-induced lifestyle changes

\begin{tabular}{|c|c|c|c|c|}
\hline & $1 / 78$ & $1 / 79$ & $6 / 79$ & $1 / 80$ \\
\hline & $\%$ & $\%$ & $\%$ & $\%$ \\
\hline Haven't made any changes & 47 & 34 & 32 & 25 \\
\hline Have made some changes & 53 & 66 & 68 & 75 \\
\hline Sticking to a budget & 22 & 22 & 22 & 24 \\
\hline Spending less on food & 10 & 20 & 22 & 26 \\
\hline Using less utilities & 24 & 16 & 16 & 29 \\
\hline Using less gasoline & 4 & 2 & 10 & 19 \\
\hline Spending less on clothes & 2 & 3 & 3 & 5 \\
\hline Spending less on entertainment & 4 & 6 & 2 & 2 \\
\hline \multirow[t]{2}{*}{ Downbeat consumer } & $12 / 76$ & $11 / 78$ & $7 / 79$ & $3 / 80$ \\
\hline & $\sigma_{0}$ & $\%$ & $\%$ & $\sigma_{0}$ \\
\hline Can afford hardly anything & 19,9 & 19,1 & 19,9 & 23,9 \\
\hline Can afford some things & 41,0 & 43,1 & 41,1 & 42,9 \\
\hline Can afford most things & 30,2 & 26,4 & 29,2 & 24,0 \\
\hline Can afford almost all things & 8,6 & 9,0 & 9,3 & 8,4 \\
\hline
\end{tabular}

of the family are attempting to find employment. Female labour force participation rates are increasing. A report in the United States ${ }^{3}$ has noted that working women view financial budgets and household needs differently from their non-working counterparts and therefore have different buying habits. For example, with regard to grocery and household products, they use more convenience-oriented products, purchase more beauty or health-oriented products and magazines and tend to consume similar products to those consumed by working men. As a result of the increase in the number of working wives, supermarket shopping will more often be done by husbands and teenagers.

During an inflationary period the consumers views as to the products they view as necessities change. With increasing inflation 'necessities' come to be viewed as discretionaries, for example new spring wardrobes, dining in restaurants, theatre going, new cars, annual holidays may no longer be viewed as necessities as the cost of necesssities increases.

Table 2, although for the U.S.A can be thought of as typical of most western countries.

The effects of inflation on the purchasing power of the consumer are increased by deepening world wide recessions and unemployment that decreases purchasing power. It is not possible to say that recessions stop inflation as evidenced in America where the inflation rate and overall Consumer Price Index has risen in peak-to-trough business cycles and prices in previous recessions have been on a much higher plateau. Marketers not only have to cope with the effects of inflation/recession but also with slow or zero growth economies. These are characterized by rising costs, falling volumes and shrinking profit margins. Another factor that marketers must take into account is that when currencies fall in value relative to other currencies as in the case of South Africa, consumers purchase locally manufactured goods instead of imported goods which are relatively more expensive.

Thus, the environment in which the marketer works has undergone and is undergoing significant changes due to
Table 2 The effect of inflation: the increasing cost of necessities, \% increase, year-to-year. Necessities = food, rent or mortgage payments, gasoline, fuel and electricity, and medical expenses

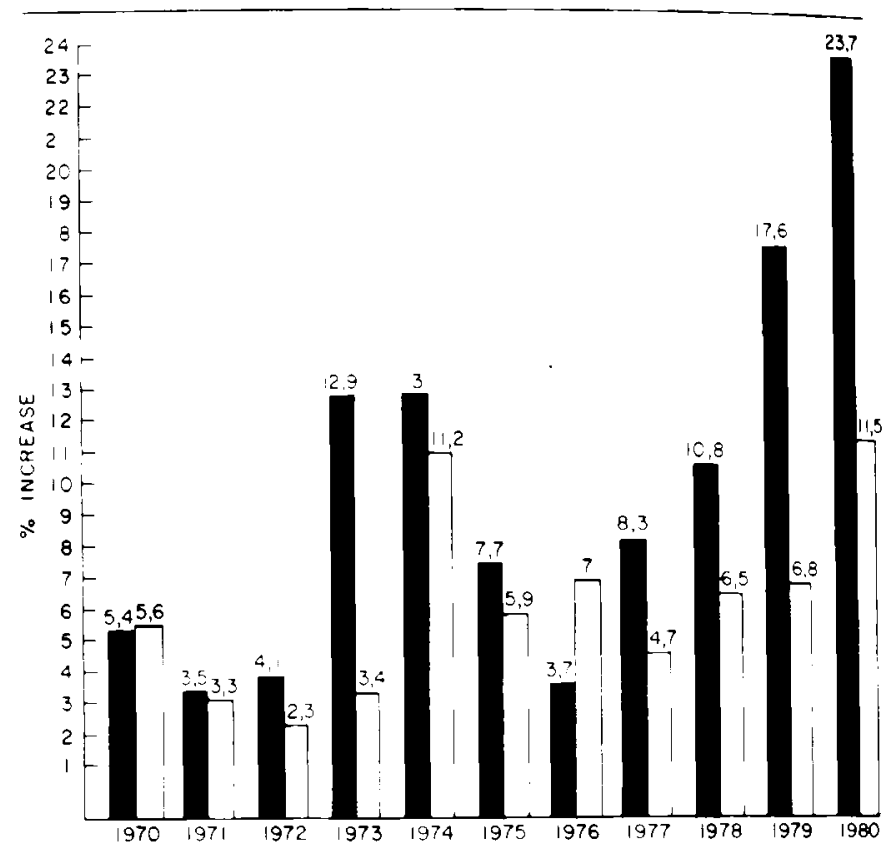

economic forces. There are implications for both management and marketers and the question is, how to respond.

A sound marketing programme still begins with an analysis of the consumers needs. Marketing research must be used effectively so that information concerning changes in demand for the firms products is obtained. Sophisticated marketing information systems will direct the marketing managers attention to important changes. The above mentioned change in consumers lifestyles necessitates companies to be more concerned with content and performance rather than external appearance. There is no doubt that products which are considered by the consumer to be inessential and/or wasteful will be discontinued. Benefits will result from the streamlining of product lines and reduction of variety so that marketers concentrate on the marketing of fewer products with greater profit potential. The emphasis must be on fewer features, less style and fewer consumer benefits. New and changed market segments have to be identified. If, for example, the new segment of working women is identified then products geared to their needs should be promoted. Marketers aware of the trend of increased shopping by husbands should increase shelf space allotted to goods that men are attracted to and stay open later because men tend to be more reluctant than women to shop in crowds. Marketers should also similarly cater for working women.

Certain market segments can be reached through the relevant type of promotion. A direct low-price appeal will work best with those people who have been forced to economize. An appeal that emphasizes conservation of scarce resources and participation in the economic process will work best with those who are motivated to economize out of virtue. Another appeal that could work with single people and young couples is that which is based on the slogan: 'economizing is fun.' The marketer must also bear in mind that there is a segment of the market whose demand for 
products is inelastic and that these consumers will continue to have a luxury-oriented life style.

The economic climate will necessitate companies becoming competition oriented, companies will have to focus on competitors as well as adopt consumer strategies. Companies will have to be aware of how competitors are reaching and satisfying their consumers as well as the prices they charge. Then they must analyse competitive as well as market reaction. The focus on competitors is important as the only way to succeed and protect their market share in a static market will be for companies to aim at decreasing their competitors market share. If the company is faced with a competitor who is cutting prices, it may have to lower prices to maintain its market share even at the expense of profits. During an inflationary period marginal profit products should be eliminated as evidenced by the fact that limited line retail stores appear to be prospering comparative to large full line retail stores. Companies should review margins and prices more often than in the past so that prices are kept in line with increasing costs. However, many companies attempt to offset inflationary pressures by passing on cost increases more rapidly thereby exacerbating the inflationary problem. The principle that should be borne in mind is that: "the consumers evaluation of a product is the maximum price which can be charged and still have an exchange take place.' ${ }^{3}$ Thus, it is not possible to pass on all cost increases as quickly as possible and not adversely affect the sales rate. Cost cannot be considered in isolation from market demand and competition. There is also the added economic phenomenon of high interest rates that adds to increased costs. These high interest rates may be able to be passed on like any other costs.

Inflation is also having a direct effect on the way goods and services are marketed. For example, door-to-door selling is no longer prevalent because of high transportation costs. The outside sales force has been reduced and many companies use telephone marketing combined with direct mail.

\section{Consumerism}

Although consumerism originated in the sixties, it is no less of an issue today. As a result of the growth of the consumer movement, businessmen have been forced to consider their social responsibilities. There is an emphasis on whether products hinder or contribute to the quality of life, whether products destroy or contaminate the environment, whether particular products are necessary to society. Philop Kotler foresees an increase in product safety and truth in advertising and in legislation and regulations aimed at protecting consumers. ${ }^{4}$ The development of a social consciousness leads to social marketing which will not only augur well for society but will also increase the firms market share and profits. Business self-interest lies in embracing social responsibility. For example, transport systems that offer discounts for the elderly during off-peak hours render a service to the elderly while at the same time exploring another market segment and filling otherwise empty seats. Another example was that provided by an insurance firm in the sixties which provided selected students discounts on car insurance in line with its research which showed that superior students had lower claims incidence that other students.
Leaders in marketing education' think that the consumer movement (buyers gaining power relative to sellers) will accelerate. Consumer-oriented groups will apply much pressure on industry, government and the media to be more responsive to consumer problems. Governmental legislation regulating consumer/marketing practices will increase, the majority of society will neglect the contention that 'the overriding business of business is to make a profit' and businesses will be required by their own operating policies to consider the long-term view of how their decisions affect the overall 'quality of life.' Furthermore, the state of business and professional ethics will become an issue of national debate.

\section{Demographic changes}

Marketers world-wide are affected by demographic changes. The percentage of consumers in different age groups is important, for as people move through the stages of the life cycle their wants, needs and purchasing power changes. Thus, in accordance with this latter change, new markets emerge as others decline or disappear completely. Marketers should therefore continually monitor demographic changes.

The importance of demographic changes to marketers can be seen if one looks at the case of the U.S.A. The postwar baby boom led to the creation of mass markets for goods and services oriented to infants in the 1950s, teenagers in the 1960 s and young adults in the 1970s. These young adults are the middle-aged in the 1980s. The diminished birthrates since the late fifties mean a diminished market segment of teenagers and young adults. The numbers of the elderly, those 65 and older, are also expected to increase. Fast growth is expected for non-family units and one-spouse homes as well as female-headed households. The family unit will, however, remain the dominant target market ${ }^{6}$. A baby boom is expected in the mid eighties because of a significant increase in potential mothers.

The above mentioned numerical age changes calls for different reactions from marketers. Products will have to be geared to the large market segment of the middle-aged. An increase in the middle-aged leads for example to an increase in home owners which provides potential for products and services. As the middle-aged rank high on income and spending scales, they will provide marketers with a strong market. In order to capture the more important femaleheaded consumer market, marketers may have to extend shop hours and perhaps engage in home delivery of bulky merchandise. The baby boom will provide sales opportunities for marketers of infant goods.

There are other characteristics of the American population that will be important to marketers. The college educated are expected to approach mass market status in the eighties. This group needs to have an above-average discretionary income and a desire for new products. The American economy has changed from a manufacturing oriented economy to a services-oriented economy and indicative of this is the fact that white collar workers now represent more than half of the work force. As far as minorities are concerned, blacks will increase significantly faster than the total population. The projection for 1990 is 29.8 million blacks, as against 25.6 million in 1978 . A relatively small, but consistently growing part of this group is upwardly 
mobile and is moving into the higher income classes. Blacks therefore become a much more important target market. The projected growth in the Hispanic population is likewise important as can be seen in the growing number of Spanishlanguage radio and TV stations, newspapers and magazines.

In South Africa the demographic fact of the greatest importance to the marketer is the expected growth of the tiack population.

'In 1975 approximately $16 \frac{1}{2} \%$ of the total popula-

tion was White, $71 \%$ Black . . By the year 2000

$13 \%$ of the population will be White, $74 \%$ Black.

By 2020 the total population growth in South Africa will be over 80 million, Black population growing to over 60 million."

At the same time an increase is taking place in the Blacks disposable income. This black market cannot be viewed as homogenous but as divided into different language and cultural groups with differing levels of urbanization, westernization and sophistication. The black market in general is thought to be undereducated and therefore lacks the ability to react to sophisticated communication programmes and although Blacks are multilingual and speak English, they cannot be said to be so proficient in English that they understand much of the current English type promotions. The marketer must therefore communicate with this market in an understandable language and via easily comprehensible concepts. The marketer must realise that black consumer demand is influenced by traditional black culture, township culture and modern white urban values. Research into the black market and its preferences then becomes very important. Whereas, in previous years Blacks emulated the Whites, today they have a spirit of self-discovery and selfidentity. 'Black consciousness' is in vogue and it is thought that blacks prefer buying from black salesmen rather than white, although they prefer dealing with an integrated business with both a black and a white sales staff. The reason for this is that to them a store that hires black sales staff only, probably keeps inferior merchandise.

\section{Technological developments}

Technology is increasing rapidly, existing products are becoming obsolete and many products that consumers will spend money on have not yet been invented. However, there will be an emphasis on the necessity of new technology and new products will only come into being if they can be said to improve the quality of life. A limiting factor on technological innovation in the eighties will be the short supply of capital. Scarce capital will be allocated primarily to developing products which will meet the needs of key customers. It has in fact been said that the key problem will be to generate capital to develop and implement technology. Nevertheless, communications systems, cable TV, rapid mass transit, cashless computerized financial transactions and medical equipment breakthroughs are some of the new technological products and processes that society will make use of.

\section{International events and competitors}

International events affect marketing. An example which illustrates this was the 1973 Middle East war and the resul- tant energy crisis. With floating currencies, businessmen have to make decisions as to obtaining cover on different currencies. Trade with other countries is also dependent on who governs them - a change in government can lead to changes in trade. It is extremely important to be aware of what is happening in the rest of the world so that marketers can assess the implications for them.

Not only international events, but international com. petitors influence marketers. Marketers can respond by emulating them, for example, they can copy the Japanese who have for a long time stressed good design, quality and after sales service. The Japanese establish market share by entering new markets with low-priced products. They are prepared to absorb losses for a while and then gradually raise their prices until they become profitable in these markets. The Japanese also research competitors products and produce counter products without the shortcomings of competitors products.

\section{Changes in the components of future marketing strategy}

(a) Product strategy

Product planning and development as well as product testing will all become more important and thus market research will be important. Technical research, postsale and presale service will all take place. There will be a greater emphasis on innovative and entrepreneurial thinking. Marketers will see the need for product development, the exploitation and development of markets for new products, the development of new methods for promoting products.

\section{(b) Pricing strategy}

That pricing should take place according to competitive levels has already been mentioned. Pricing which is based on government rules and regulations will probably become more important. The marketer will engage in value pricing and as mentioned previously will have to cut prices to maintain market share even at the expense of profits. Margins and prices will have to be reviewed frequently.

\section{(c) Promotional strategy}

Broadcast media advertising will be used. Recent innovations in promotional strategy include buying by video the electronic catalogue by means of which customers are able to request information on products and can participate in surveys. In-home shopping is the shopping of the future and consumers will be able to obtain supplementary product information from the television screen. As the importance of regional marketing grows, promotions will become regional. Retailers will choose the programs in accordance with their regional objectives. It is well to note that consumers are developing hostility toward advertising and believe that advertising can sell products that no one wants, needs or values.

\section{(d) Distribution strategy}

Manufacturers are expected to develop and assist the channel of distribution. Emphasis will be placed on warehousing and inventory control as well as transportation because of the costliness of distribution. 
Thus, it can be seen that the issues that have been discussed will pose new challenges for marketers. There is a real need for marketers to focus their attention on issues such as these.

\section{References}

1. Arbose, J. 'Challenge of the Eighties,' Int. Management 35, May 1980, p.43

2. Marketing in the Eighties, Sales and Marketing Management 123 , November 12, 1979, p.29.
3. Keane, J.G. ' 2001 is Approaching Fast; are Marketers Ready to Seize Tomorrow's Opportunities?'

4. Kotler, P. 'Meeting the Marketing Challenges of the 1980s,' Int. Management, May, 1980.

5. 'The Future of Marketing as Seen by Leaders in Marketing Education' in Lacznik, G.R., Lusch, R.F. and Udell, J.G., 'Marketing in 1985: A View from the Ivory Tower', J. Mark. October 1977, pp.47-56.

6. This statement and paragraph is derived from Taylor, T.C. 'Marketers complete guide to the 1980s,' Sales and Marketing Management 123, December 10, 1979, pp.27- 57.

7. Feldberg, M. 'Marketing, Yesterday, Today and Tomorrow,' Insight, May 1976, p.24. 